\title{
Civil/nonprofit szervezetek a kohéziós politikában - elméleti alapok
}

\author{
Civil and non-profit organisations in the \\ cohesion policy - theoretical background
}

\author{
REISINGER ADRIENN
}

KULCSSZAVAK: civil/nonprofit szervezetek, részvételi demokrácia, kohéziós politika, partnerség

ABSZTRAKT: Tanulmányomban arra keresem a választ, hogy a civil/nonprofit szervezeteknek milyen szerepe lehet a régiók formálásában, ezáltal az EU kohéziós politikájának alakításában. A kohéziós politika fő célkitúzése, hogy elősegítse az EU régióinak egymáshoz való közeledését, elsődlegesen anyagi és szakmai segítségnyújtás biztosításával. Kérdés az, hogy ebben mi lehet a civil/nonprofit szervezetek feladata, továbbá, hogy milyen elméleti alapja van a szervezetek részvételének.

Elöször a civil/nonprofit szervezetekre vonatkozó fogalmi rendszert ismertetem, majd a kohéziós politikában való részvétel megalapozásaként bemutatom a részvételi demokrácia koncepcióját, területi vonatkozásait és technikáit, kiemelten a partnerséget mint a kohéziós politika egyik alapelvét. Tanulmányom utolsó részében ismertetem, hogy a civil/nonprofit szervezetek milyen formában tudnak megjelenni a kohéziós politika folyamatában, majd a részvétel előfeltételei következnek. Kifejtem, hogy a kelet-közép-európai térségben milyen sajátosságok és hiányosságok vannak a részvételt illetően. A tanulmány rövid összegzéssel és javaslattétellel zárul.

Az volt a célom, hogy áttekintő összefoglalást adjak a civil/nonprofit szervezeteknek a kohéziós politikában játszott szerepéről és ennek elméleti alapjairól (részvételi demokrácia), továbbá, hogy rövid áttekintést adjak arról, hogy a civil/nonprofit szervezetek a jövőben milyen szerepet fognak játszani a kohéziós politikában.

KEYWORDS: civil and non-profit organisation, participatory democracy, cohesion policy, partnership

ABSTRACT: Research (Bartal 2005, Kuti 1998, Jenkins 1997, Kákai 2009, Szakál 2004, Nárai 2008, Reisinger 2010) has shown that civil and non-profit organisations have a significant role in shaping democracies, in developing local social life and in strengthening the social capital.

Civil and non-profit organisations show importance not only in social and economic life but also in development policies. The focus of this study is on those organisations which can take an active part in development processes, thus also

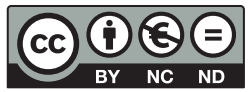


in the European cohesion policy. In the cohesion policy field, organisations may have a role in two ways:

- at local, regional and national levels: shaping development policies

- at a European level: shaping the cohesion policy

By this approach, not all civil and non-profit organisations can and should be part in the development process. Only organisations without financial or functional problems should and can be active in participating in the life of a settlement or a region.

Civil and non-profit organisations can take part in the cohesion policy in various ways:

- they can be a communication channel between decision-makers and citizens

- they can create jobs

- they can connect to European networks through EU projects

- they can manage EU projects

- they can contribute to development with their financial support

- they can be part of cross-border co-operations

- they can strengthen the citizens' European identity

- they can create new innovative resources, etc.

How can the role of the civil and non-profit organisation be made more effective? According to a report published by the European Commission in 2010, it is most important to strengthen partnerships among regions. The local development context plays a big part, as was already emphasised by the Barca Report (2009). One of the most important tasks is to give a more active role to the local and regional levels and to find communication methods which can serve these goals. The European Economic and Social Committee urges to compile a Good Practices Handbook to help organisations find the most suitable methods at the local level.

In the author's opinion, civil and non-profit organisations will assume a more significant role in formulating the cohesion policy of the future, not only because this is also suggested by European Union documents, but also because the social and economic processes are becoming increasingly complex. As a result, efficient decision-making processes need both decision-makers and civil and non-profit organisations, because the latter know the situation at local and regional levels.

Civil and non-profit organisations are essential when it comes to knowing and applying participatory methods appropriate for communicating the opinions of the citizens. Accordingly, only those organisations should be involved which represent not only their members but also the citizens of the region in question. This makes them more effective both on the national and the supranational level.

\section{Témafelvetés}

A világon számos kutatás bizonyította már (pl. Bartal 2005, Kuti 1998, Jenkins 1997, Kákai 2009, Szakál 2004, Nárai 2008, Reisinger 2010), hogy a civil/nonprofit szervezeteknek milyen nagy szerepe van a demokráciák építésében, a helyi társadalmi élet fejlesztésében és a társadalmi tőke ${ }^{1}$, valamint a bizalom megerősítésben akár nemzetek alatti, akár nemzetek feletti szintről beszélünk. A civil/nonprofit szervezeteknek számos társadalmi (önszerveződés lehetősége, önkéntes munka, demokráciák formálása) és gazdasági (közjavak előállítása, 
GDP-hez való hozzájárulás, redisztribúciós szerep, foglalkoztatóként való megjelenés) jelentősége van (Csanády 1998, Kuti 1998, Jenkins 1997, Bartal 2005), azonban nem hanyagolható el a szervezetek fejlesztéspolitikai szerepe sem (Reisinger 2010). Ez utóbbi szerep kétféle megközelítésben értendő:

- a szervezetek egy része közvetlenül és aktívan megjelenik az egyes területi szintek fejlesztésének formálásában, a döntéshozatalban; rendszeresen hallatja hangját különböző fórumokon, és megpróbál hatást gyakorolni a területi politikát formáló szereplőkre;

- a szektor másik részébe tartozó szervezetek a mindennapi tevékenységükön túl nem vesznek részt aktívan és közvetlenül a fejlesztési folyamatokban, viszont azáltal, hogy működnek, komoly közösségfejlesztő erővel bírnak, hatni tudnak a társadalom szereplőire, tehát közvetetten befolyásolni képesek környezetük formálását.

Tanulmányom tárgyát a fejlesztéspolitikában közvetlenül is aktív civil/nonprofit szervezetek adják, a továbbiakban róluk lesz szó. Feltehető a kérdés, hogy miben lehetnek aktívak ezek a szervezetek? Erre tanulmányom szempontjából a legfontosabb válasz, hogy a régiók fejlődésének alakításában, ezáltal a kohéziós politika formálásában. Ezt a szerepet alapvetően kétféle módon tudják betölteni a szervezetek:

- helyi, regionális és nemzeti szinten aktívak a területi politika alakításában,

- EU-s szinten vesznek részt a kohéziós politika formálásában.

Megközelítésemből látszik, hogy a tanulmány feltételezi: nem minden civil/nonprofit szervezetnek feladata és nem is minden szervezet képes arra, hogy fejlesztéspolitikai szerepet ellásson. Erre azon szervezetek képesek elsődlegesen, amelyek nem küzdenek működési és financiális problémákkal², és alapítási célként vagy mindennapi tevékenységük mellett környezetük formálásában is aktívak.

Tanulmányom célja, hogy a fenti keretrendszerben bemutassam a civil/nonprofit szervezeteknek a kohéziós politikában megjelenő szerepeit, továbbá, hogy felhívjam a figyelmet ennek fontosságára.

\section{Civil/nonprofit szervezetek: fogalmi rendszer}

A civil társadalomra, szervezeteire (civil szervezetek) és a nonprofit szektorra vonatkozóan nagyon sokféle megközelítés, definíció született az elmúlt években a hazai, valamint a nemzetközi szakirodalomban. Ebben a fejezetben ezek közül mutatok be néhányat, kitérve az EU-ban használt értelmezésekre is. Ezek alapján ismertetem, hogy a tanulmány mit ért civil/nonprofit szervezeten. 


\section{Civil társadalom - civil szervezet}

A civil társadalom kifejezést a 18. században használták először, de magáról a társadalmi jelenségről már Arisztotelész és Cicero is írt. A 18. században a kifejezést „a társadalmi kölcsönösség szférájának megjelölésére” (Seligman 1997, 19.) használták, majd a 19. században a társadalomnak azt a szféráját írták le vele, amely az állami szférától elkülönül. Seligman szerint a fogalom tudományos értelmezése még ma is hiányzik, a korábbi évszázadokban is eltérően határozták meg a fogalmát. Abban közösek voltak a meghatározások, hogy „a köz és a magán, az egyéni és a társadalmi, a közerkölcs és a magánérdek, az egyéni szenvedélyek és a közüdv" (Seligman 1997, 20-21.) problémájából indultak ki. Seligman a civil társadalmat olyan küzdőtérként képzeli el, ahol a magánszemélyek érvényesíteni tudják érdekeiket.

Cohen és Arató (1988 - idézi Bartal 2005) közösen az 1980-as évek végén meghatározták, hogy melyek azok a tényezők, amelyek a civil társadalom kritériumrendszerét alkotják. Értelmezésükben a civil társadalom egyfajta kapcsolódási pont a gazdasági és az állami szféra között, amelynek szervezetei alapításukban és működésükben alapvetően különböznek az állami és piaci szervezetektől, és egyfajta állam nélküli társadalomként értelmezhetők. A szerzők kiemelik, hogy a civil társadalom nem azonosítható a magánszférával, és szerepe abban rejlik, hogy szembesíti az állami szereplőket az általuk megtestesített értékekkel.

Bartal Anna Mária könyvében a következő meghatározást lehet olvasni: „a civil társadalom fogalmába azok az állampolgári kezdeményezések tartoznak, amelyekben a polgárok önkéntesen vesznek részt érdekeik és értékeik megjelenítése, védelme érdekében, és amely kezdeményezések az államtól elkülönülve, autonóm módon múködnek" (Bartal 1999, 19-20.).

A fentiek alapján a tanulmány értelmezésében a civil társadalom minden olyan kezdeményezést magában foglal, amelyet az állampolgárok önkéntesen, mindenféle külső kényszer nélkül hoztak létre. Az ilyen kezdeményezések közé tartoznak többek között a civil szervezetek is.

\section{Nonprofit szervezetek}

A civil társadalom, civil szervezet fenti fogalmi megközelítéseivel még ma is sokan azonosítják a nonprofit szektort, ami azonban ebben a formában nem állja meg a helyét, ugyanis a civil társadalmon belül a nonprofit szektor csak azokat a formalizált, intézményesült szervezeteket foglalja magában, amelyeknek hivatalos, jogilag definiált státusa van (Kuti 1998, Bartal 2005). Ebből következik, hogy a nonprofit szektor bizonyos értelemben szűkebb kategória, mert nem foglalja magában a civil szervezetek egészét, de egyben tágabb kategória is, mert a nonprofit szervezetek között találhatóak olyan szervezetek $^{3}$, amelyeket nem egyéni kezdeményezés, hanem állami és/vagy önkormányz- 
ati akarat hoz létre. Ilyenek ma Magyarországon a közalapítványok, köztestületek és közhasznú társaságok. (Utóbbiak 2007. július 1-je óta nem alapíthatók, 2009. június 30-áig át kellett alakulniuk nonprofit gazdasági társasággá vagy meg kellett szünniük.) Ezen szervezetek elsősorban alapítóik miatt nem tartoznak sem a civil társadalom, sem a nonprofit szektor fogalmi kategóriájába. Ennek ellenére a magyar jog a nonprofit szervezetek közé sorolja őket. Több szerző a fentiek miatt kvázi nonprofit szervezetekként említi őket, és a magyar nonprofit szektor dualitásáról beszél (Bartal 1999, Harsányi 1999, Nárai 2008).

Hazánkban az 1990-es évek első felétől vált általánossá a civil szektor elnevezésére a nonprofit kifejezés. Ez az elnevezés a szektor legfőbb jellegzetességét ragadja meg: az idetartozó szervezetek nem profitorientáltak, nem tartoznak a piaci szektorhoz. Ez nem jelenti azt, hogy ezen szervezetek nem végezhetnek olyan vállalkozási és egyéb tevékenységet, amelyből nyereségük származna, azonban ezt a nyereséget nem oszthatják fel, csak céljaik megvalósítása érdekében használhatják fel (Kuti 1998).

Ezen a kritériumon kívül további öt olyan megkülönböztető eleme van a nonprofit szervezeteknek, amely elválasztja őket a piaci, az állami és az informális szférától. Ez a felosztás tulajdonképpen Anheier és Salamon (1995) operacionális-strukturális definíciójának felel meg. Ez a meghatározás az 1990-es években a John Hopkins University által folytatott nemzetközi összehasonlító kutatások eredményeként jött létre. A definíció egy fogalmi készlet, amely a szektor főbb jellemzőit tartalmazza. Ezek a következők:

- müködési autonómia és szervezeti elkülönülés a kormányzati szektortól;

- intézményesültség, önálló jogi személyiség;

- az önkéntesség legalább minimális szintje;

- közhasznúság;

- pártpolitikai tevékenység tiltása.

\section{Európai uniós megközelítés}

Az Európai Bizottság 1997-es dokumentumában - amely az első és legfontosabb dokumentum volt az EU és a civil szervezetek ${ }^{4}$ kapcsolatára vonatkozóan (,Az önkéntes szervezetek és az alapítványok európai szerepvállalásának erősitéséról" (COM (97) 241 végleges)) - meghatározza a civil szektorba tartozás fő kritériumait, amelyek a következők:

- önkéntesség: valamilyen célból közösen tevékenykedő emberek csoportja alkotja a szektort;

- formalitás: a civil szerveződések meghatározott szervezeti formákban müködhetnek;

- a profitfelosztás tilalma: a szervezetek a keletkezett profitot nem oszthatják fel, hanem a tevékenységükbe kell visszaforgatniuk; 
- kormányoktól való függetlenség: a szervezetek alapításában a kormánytól független személyek, szervezetek vehetnek részt;

- a közjó szolgálata: a szervezetek olyan tevékenységeket folytatnak, melyek a közösség érdekeit szolgálják.

2000-ben az Európai Unió Gazdasági és Szociális Bizottsága (EGSZB) is hasonló ismérveket sorakoztatott fel a civil szektor kritériumaira vonatkozóan (Az Európai Bizottság és a nem kormányzati szervezetek: szorosabb partneri kapcsolat, 2000). Ezenkívül már 1999-ben konkrét definíciót adtak a civil szektorra vonatkozóan, amelynek fő elemei a következők (A szervezett civil társadalom szerepe és hozzájárulása az európai konstrukciókhoz, 1999):

- az államtól, piactól független szervezetek;

- a civil szektor egyfajta kommunikációs szféra;

- az alábbi elvek alapján működik: autonómia, pluralizmus, szubszidiaritás, szolidaritás, felelősség.

\section{Civil/nonprofit szervezetek - szerzói megközelítés}

Mivel a civil és nonprofit szervezetek fogalmi rendszere összetett, és a két szervezeti kör részben fedi is egymást (legalábbis magyarországi viszonylatban), így a szerző a civil/nonprofit szervezet kifejezés mellett foglal állást. Civil/nonprofit szervezeteken ért minden olyan szerveződési formát, amelyet részben vagy egészben állampolgári akarat hozott létre önkéntesen egyéni, közösségi vagy közcélok megvalósítása érdekében.

\section{A kohéziós politikában való részvétel alapjai - a részvételi demokrácia}

A civil/nonprofit szervezetek létrehozásának egyik fontos társadalmi jelentősége, hogy lehetőséget adnak az önszerveződésre (Kuti 1998). Az emberek civil/nonprofit szervezetek létrehozásával kifejezhetik saját igényeiket, érvényesíteni tudják érdekeiket. Az állami, illetve a piaci szektor nem minden esetben képes meglátni azokat a problémákat, amelyekkel az emberek nap mint nap küzdenek, és nem minden esetben tudják kielégíteni a felmerült, egyre speciálisabb igényeket. Az embereknek civil/nonprofit szervezetek alapításával, illetve az ilyen jellegü szervezetekben végzett önkéntes munka által lehetőségük nyílik arra, hogy saját elképzeléseik szerint, a társadalom aktív szereplőjeként oldják meg a felmerülő problémákat, elégítsék ki a felmerült igényeket.

Amikor a civil/nonprofit szervezetek szerepéről beszélünk, elengedhetetlen kiemelni azt a tényt, hogy a szektor a mai demokráciák egyik nélkülözhetetlen elemeként és alappilléreként értelmezhető (Jenkins 1997). Ezen 
szerepkör értelmében a szektor az egyének egymás közötti kapcsolatainak létrehozását segíti elő az egyéni és közösségi célok összekapcsolásával, kontrollálhatja a kormány túlkapásait, és elősegítheti az egyének részvételét a közösségi szint működésében. Claus Offe (Offe 1991, 116 - idézi Pálné 2008, 258.) kifejti, hogy a demokratikus működéshez fejlett és jól működő civil társadalomra van szükség: „....a kifejlett civil társadalmi komplexitás hiánya olyan kérdések uralmához vezet, amelyek a konfliktushoz ugyan elegendők, kompromisszumra viszont nem alkalmasak." A civil/nonprofit szervezetek demokráciában betöltött szerepéről Kende $(1999,18$.$) úgy fogalmaz, hogy a szervezetek addig képezik a demokráciák egyik$ tartópillérét, ,....amíg nyitva állnak a demokratikus akaratképződés csatornái [...], s amíg a polgárok készek arra, hogy a demokrácia intézményeit működtessék."

A világ demokratikus berendezkedésű államainak működési alapja a képviseleti demokrácia rendszere, amelynek értelmében az állampolgárok adott időszakonként képviselőt választanak maguknak, rá bízva, hogy felelősen döntsön az országot, az adott területi egységet érintő kérdésekben (Sartori 1999). A képviseleti demokrácia rendszere a 20. század második felében ${ }^{5}$ került abba a helyzetbe, hogy nem minden esetben volt képes az érdekeket, különösen a helyieket megfelelően érvényesíteni (Ugrin, Varga 2007, Nizák, Péterfi 2005). Megjelent az állampolgárok részéről az az igény, hogy ők is szeretnének közvetlenül beleszólni saját környezetük fejlődésébe, nemcsak a választások és egyéb népszavazások alkalmával, hanem a köztes időszakokban is: akár közvetlenül, akár közvetetten, civil/nonprofit szervezetek alapításán keresztül.

\section{A részvételi demokrácia koncepciója}

A részvételi demokrácia működése azon az elven alapul, hogy az állami szereplők mellett a társadalom és a gazdaság szereplői ${ }^{6}$ is részt vesznek a környezetüket alakító folyamatokban, teszik ezt önként és teljes jogú félként (Sartori 1999).

Ugrin, Varga (2007), Nizák, Péterfi (2005), Sartori (1999) és Kulcsár (1997) véleményét osztom abban, hogy a jövő demokráciaformája a képviseleti és a részvételi demokrácia között található. Ennek oka, hogy a részvételi demokrácia önmagában nem valósulhat meg, ugyanis a részvételi jogok között található a javaslattételi, az informálási és informálódási, valamint a vitatkozási jog mellett a döntési jog is, amelynek értelmében az állampolgároknak lehetőséget kell kapniuk minden fejlesztési és közügyi döntésben. Ennek a gyakorlatban nincsenek meg a megvalósítási feltételei. Így a részvételi demokrácia csak a közvetett demokrácia kiegészítő elemeként jelenik meg, azt értve ezen, hogy a képviseleti rendszer megtartása elengedhetetlen (hiszen ez a mai demokráciák alapja), viszont szükség van ennek kiterjesztésére, illetve szélesebb körben történő alkalmazására a részvételi elv alapján úgy, hogy teret kapnak a szereplők a döntések előkészítésében, a megvalósításban, de a döntés joga továbbra is a képviselők kizárólagos joga marad. Nizák Péter és Péterfi Ferenc (2005) megfogalmazásá- 
ban ez a képviseleti demokrácia kibővítését jelenti részvételi elemekkel. A cél az, hogy minél több szereplő minél több kérdésben fejtse ki a véleményét, járuljon hozzá a döntések meghozatalához, és vegyen részt a megvalósításban. Továbbá a fentiek értelmében, a gyakorlatban a képviseleti demokrácia részvételi elemekkel történő megvalósítására használható az aktív demokrácia kifejezés (Reisinger 2010), amely olyan demokráciaformát jelöl, amelyben az állampolgárok aktívan részt vesznek a fejlesztési folyamatokban, együttmüködve az általuk választott képviselőkkel és egyéb helyi szereplőkkel.

\section{Miben és milyen szinteken lehet részt venni?}

A részvételi demokrácia a rendszeres választásokon és népszavazásokon túl a javaslattételi, az informálási és a vitatkozási jog keretében sok más lehetőséget is biztosít a társadalmi és gazdasági szereplők, így a civil/nonprofit szervezetek részvételére, amelyek a következők lehetnek (Kákai 2004, Bartal 2005, Reisinger 2010):

- a helyi közügyek alakítása;

- jogszabályok létrehozása;

- aktuális hétköznapi ügyek megvitatása;

- az önkormányzati munkában való részvétel;

- beruházások, projektek menedzselése, megvalósítása;

- közösségépítés- és formálás;

- kommunikációs csatornaként való működés (hídszerep);

- a települések fejlesztési programjainak tervezése, megvalósítása;

- területi szintek fejlesztési programjainak tervezése, megvalósítása;

- nemzeti fejlesztési tervek tervezése, megvalósítása;

- gazdaságfejlesztési tervek tervezése, megvalósítása stb.

Több szerző foglalkozott azzal, hogy a részvételnek milyen szintjei lehetnek, és ezek közül melyik az ideális. A következőkben a fontosabb elméletek bemutatása következik.

Arnstein 1969-ben alkotta meg a társadalmi részvétel létráját (1. ábra), amelyben 8 fázisban különíti el a részvétel mélységét a teljes passzivitástól az aktív jelenlétig.

A létra alsó két szintje fejezi ki a szereplők teljes passzivitását, majd a következő három szint jelenti a részleges részvételt. Ennek tartalmi elemei között az informálás és a felmerült problémák kooperatív megoldása található. Arnstein a társadalmi részvétel legitimációjaként értelmezi az informálás szerepét, hiszen információk biztosítása nélkül nem lehet részt venni semmiben, így a helyi és központi állam egyik nagyon fontos szerepe, hogy információkhoz jutassa a lakosságot és a többi helyi szereplőt. A közeledés szerepét úgy értelmezte Arnstein, hogy bár a szereplőknek nincsen döntési joguk, de véleményezhetik a döntések előkészítése során az előzetes információkat. A partnerség már ennél magasabb fokú együttműködést jelent, azonban igazán a 8. létrafok fejezi ki az állampol- 
1. ábra: A közösségi részvétel létrája

The ladder of community participation

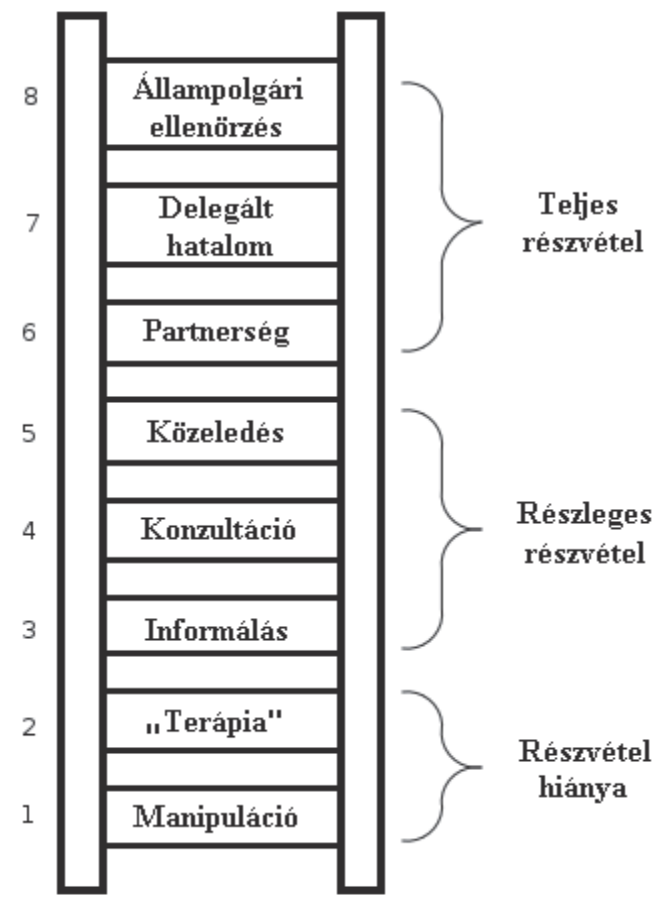

Forrás: Arnstein 1969.

gárok „uralmát”, ahol egyik szereplőnek sincs abszolút kontrollja, minden helyi szereplő ugyanolyan jogokkal és kötelezettségekkel rendelkezik. A szerző elgondolásában egy társadalomban mindhárom szint megvalósulhat, azonban ahogy arra már korábban utaltam - a szereplők döntésekben való részvétele gyakorlati megvalósításának nincsenek meg a feltételei.

A részvétel egy másik aspektusa a civil/nonprofit szervezetek aktivitását kétféleképpen közelíti meg: a konzultáció és a részvétel oldaláról. A konzultáció biztosítja azt a lehetőséget a szervezetek számára, hogy elkészült törvényjavaslatokról, stratégiákról, tervekről véleményt mondhassanak, míg a részvétel ennél sokkal szélesebb körübb tevékenység, amely a teljes stratégiaalkotás, törvényhozási folyamat alatt biztosítja a szervezetek jelenlétét. Young és Qiunn (2002) a folyamat hat lépését sorolja fel: a probléma megfogalmazása, alternatívák megfogalmazása, a preferált ötletek definiálása, tervezés, megvalósítás.

A társadalmi részvétel egy másik megközelítését mutatja be az 1. táblázat, amely 5 szintet tartalmaz az informálástól a felhatalmazásig.

Több szerzővel egyetértve (Chanan 1997, Pálné 2008, Burns, Hambleton, Hogget 1994, Gerston 2002, Coleman 2005) én is azon az állásponton vagyok, 
1. táblázat: A társadalmi részvétel módjai Methods of the social participation

\begin{tabular}{lc}
\hline 1. Informálás & $\begin{array}{c}\text { Cél } \\
\text { 2. Konzultáció }\end{array}$ \\
$\begin{array}{c}\text { Elérni, hogárok, szereplök informánón a kiadott információk- } \\
\text { kal kapcsolatosan visszajelzések is } \\
\text { történjenek }\end{array}$
\end{tabular}

3. Bevonás

4. Együttmüködés, Partnerség

5. Felhatalmazás
A fejlesztések során közvetlenül az érintett szereplőkkel dolgozni

A teljes fejlesztési folyamatban partneri együttmüködés (alternatívák kidolgozása, alternatívák közül megvalósitható kiválasztása)

A végső döntés is az érintett szereplők kezében van
Igéret

Információk biztosítása

A visszajelzések döntésre gyakorolt hatásáról informálják a szereplőke†

A vélemények megjelennek az alternatívában, és történik visszajelzés róluk

$$
\begin{gathered}
\text { A vélemények lehetố } \\
\text { legmagasabb szintü } \\
\text { figyelembevétele }
\end{gathered}
$$

Teljes mértékben a szereplők véleménye, döntése a mérvadó

Forrás: Outer Suburban/Interface Services and Development Committee 2006.

hogy az ideális részvételi forma a partnerség (az 1. ábrán a 6. szint), mert ebben az esetben valósulnak meg mindazon jogok, amelyek mentén a részvételi demokrácia működőképes lehet. A partnerség az Európai Unió kohéziós politikának egyik alapelve 1988 óta, részletesen „A részvétel ideális szintje: a partnerség" című alfejezetben lesz szó róla.

\section{Részvételi demokrácia és a területi dimenzió}

Amikor részvételi demokráciáról beszélünk, nagyon fontos kérdéskör, hogy mindez milyen területi szinten érvényesíthető? A tanulmány témája szempontjából kétféle területi dimenziót különítek el elsődlegesen a civil/nonprofit szervezetekre gondolva:

- nemzeti és ez alatti területi szint,

- nemzetek feletti szint, például Európai Unió.

A fentieken azt értem, hogy külön kell kezelni a részvételi demokrácia szereplőinek körét - a civil/nonprofit szervezetekét is - abból a szempontból, hogy milyen területi dimenzióban képesek együttműködni a döntéshozókkal, és viszont. A kis helyi szervezetek elsődlegesen településük érdekeit figyelembe véve tudnak aktívan részt venni akár a település szépítésében, akár az önkormányzat bizottsági munkájában. Vannak olyan szervezetek is, amelyek mindezen feladatokat már a település határát átlépve regionális vagy akár nemzeti szinten tudják végezni. Ezen szervezetek célja, hogy beleszólhassanak az ország, a régió fejlődési folyamataiba, a fejlesztési elképzelések alakításába. A nemzetek feletti 
szinten (tanulmányomban ezen az EU-t értve) az uniós döntéshozatalban nagyobb hangsúlyt kapnak általában azok a civil/nonprofit szervezetek, amelyek nemzeti vagy nemzetek feletti szinten szerveződnek, akár egymás tagszervezeteiként. Felmerül a kérdés, hogy egy több országot átfogó integráció müködésében miért van szükség a civil/nonprofit szervezetekkel való együttmüködésre? Egyáltalán szükség van-e rájuk ezen a szinten is? A válasz ma már egyértelmüen igen. Az Európai Bizottság az 1997-ben kiadott „Az önkéntes szervezetek és az alapítványok európai szerepvállalásának erősítéséről" című dokumentuma gyakorlatilag megalapozta a civil/nonprofit szervezetek és az EU kapcsolatát, feltárta a fennálló problémákat, és megoldási javaslatokat tett ezek feloldására. Továbbá többek között a 2009-ben életbe lépett Lisszaboni Szerződés is hangsúlyozza a szervezetekkel való együttműködés, egyeztetés fontosságát: „Az intézmények az érdekképviseleti szervezetekkel és a civil társadalommal nyílt, átlátható és rendszeres párbeszédet tartanak fenn" (8b. cikk [2]).

Az elmúlt években zajló társadalmi, gazdasági folyamatok és az EU felépítéséből adódó negatívumok egyre inkább előtérbe helyezték a civil/nonprofit szervezetekkel való együttműködés fontosságát. A fö okok öt probléma köré csoportosíthatók (Arató 2000, 2005, Gesztiné, Csanády 2003, Merkel 1997, Scharpf 1999, Siedentop 2000):

- Demokratikus deficit: Az Európai Unió működésének alapja a demokratikus értékek érvényesítése, azonban az intézményrendszer felépítéséből és működéséből adódóan nem képes minden polgár érdekeit képviselni. Ennek következtében az EU eltávolodhat az állampolgároktól, akik emiatt jogosan érezhetik úgy, hogy csak nehezen tudnak beleszólni az őket érintő kérdésekbe. A hiányosság három szinten jelenik meg (Merkel 1997): a döntéshozatalban, a döntésvégrehajtásban és az érdekkifejezésben.

- Legitimáció: Egy rendszer legitimitása annál nagyobb, minél nagyobb mértékben vesznek részt az állampolgárok a döntéshozatalban, minél inkább elfogadják a döntéseket.

- Menedzsmentdeficit: az EU intézményeinek humánerőforrása korlátozott, így rákényszerülnek arra, hogy külső szereplők segítségét is igénybe vegyék a döntéshozatal során, ezért a szereplőkkel való együttmüködés nemcsak lehetőség, de egyfajta kényszer is.

- Kommunikációs problémák: az EU állampolgáraihoz nem megfelelően jutnak el az információk, ennek feloldásában tudnak a civil/nonprofit szervezetek segíteni.

- A jóléti szolgáltatások biztosításának problémái: a civil/nonprofit szervezetek olyan igényeket is ki tudnak elégíteni, amire az állami és/vagy piaci szereplők nem képesek.

A fenti hiányosságok megléte miatt ma már egyértelműen elfogadott tény, hogy az állampolgároknak és a civil/nonprofit szervezeteknek nemcsak tagállami, hanem európai uniós szinten is jelentős szerepük van a döntések meghozatalát megalapozó folyamatokban. 
Az Európai Unió Lisszaboni Szerződése (2009) közösségi jogként rendelkezik mind a képviseleti, mind a részvételi demokrácia elveiről. Eszerint az EU müködése a képviseleti demokrácia elvén alapul: minden állampolgárt megillet az a jog, hogy a döntések nyilvánosan és a polgárokhoz legközelebb eső szinten szülessenek. Továbbá kinyilvánítja, hogy a polgárok és érdek-képviseleti szervezeteik az EU tevékenységéről véleményt mondhassanak és párbeszédet folytathassanak az intézményekkel.

- „Az intézmények az érdek-képviseleti szervezetekkel és a civil társadalommal nyílt, átlátható és rendszeres párbeszédet tartanak fenn” (8b. cikk [2]).

- „Az Európai Bizottság, annak érdekében, hogy biztosítsa az unió fellépéseinek koherenciáját és átláthatóságát, az érintett felekkel széles körü előzetes konzultációkat folytat"( 8b. cikk [3]).

A civil/nonprofit szervezetekkel való kapcsolattartásban a Régiók Bizottságának, az Európai Gazdasági és Szociális Bizottságnak, továbbá az Európai Bizottság Regionális Politikai Főigazgatóságának és az Európai Parlament Regionális Fejlesztési Bizottságának óriási szerepe van. Ezek a szervezetek közvetlenül is kommunikálni tudnak a helyi szervezetekkel és az ezeket összefogó ernyőszervezetekkel. Ehhez természetesen az kell, hogy az érintett szervezetek is tisztában legyenek azzal, hogy számukra is megadatott, hogy megfelelő fórumokon elmondhassák a véleményüket a térségükben történtekről, tájékoztassák az EU-szintü döntéshozókat a helyi folyamatokról. A kommunikációban nagy segítséget tudnak nyújtani a régiókat képviselő brüsszeli irodák, amelyeknek munkatársai jól ismerik az EU-szintü történéseket, így akár egyfajta kommunikációs csatorna szerepét is képesek betölteni.

\section{Civil szervezetek a kohéziós politikában}

\section{Kohéziós politika és a civil/nonprofit szervezetek}

A kohéziós (korábban regionális) politika az Európai Unió egyik közösségi politikája 1987 (az Egységes Európai Okmány hatályba lépése) óta, amelynek fő célkitűzése a régiók közötti fejlettségi különbségek csökkentése azok fejlesztésén keresztül. Ezenkívül további alapvető célja (Rechnitzer, Smahó 2006) a növekedés, a stabilitás és fenntarthatóság, a kiegyenlítés és a környezet megóvása. A célok elérése érdekében az EU pénzügyi támogatást (alapvetően a strukturális alapokon és a Kohéziós Alapon keresztül) nyújt az egyes tagországok régiói számára adott kritériumrendszer alapján. A 2007-2013-as tervezési időszakban a fő célkitűzések a következők (Horváth 2007): konvergencia, regionális versenyképesség, foglalkoztatás és európai területi együttmüködés. 
Az Európai Unióban, ahogy az előző fejezetben bemutattam, az elmúlt években egyre nyilvánvalóbbá vált, hogy a szakpolitikák alakításában tennivalója van a társadalmi és gazdasági szereplőknek, így a civil/nonprofit szervezeteknek is. A kohéziós politika esetében véleményem szerint a fentiekben felsorolt okok közül a demokratikus deficit a legmeghatározóbb. Habár a régiók fejlesztésére vonatkozó stratégiai tervek, pályázati kiírások és elbírálások nemzeti szinten zajlanak, a fó keretek kialakítása az EU-s intézményekben történik, viszont az ott ülő szakemberek nem mindig képesek pontosan átlátni, hogy mi is zajlik helyi, regionális szinten. Ezért szükség van arra, hogy a döntéshozók kommunikáljanak a szervezetekkel.

\section{Miben tudnak hozzájárulni a civil/nonprofit szervezetek a kohéziós politika sikeréhez?}

Az előző fejezetek alapján látható, hogy a civil/nonprofit szervezeteknek milyen nagy szerepe van a mai demokráciák építésében, formálásában, helyi, regionális, nemzeti és EU-s szinten egyaránt. A kohéziós politikában is nagy jelentőséggel bír jelenlétük mind tagállami, mind közösségi szinten. Az elméleti megalapozások után arra szeretnék kitérni, hogy melyek lehetnek azok a szerepek, funkciók, amelyekkel a civil/nonprofit szervezetek hozzájárulhatnak, illetve kapcsolódhatnak a kohéziós politika tervezési, megvalósítási és értékelési folyamatához (ECAS 2005, Arató 2005, Sasvári 2008):

- kommunikációs csatornaként kapcsolódás az állampolgárokhoz: vélemények közvetítése az állampolgárok és a döntéshozók között;

- munkahelyteremtés;

- kapcsolatépítés a civil/nonprofit szektoron belül és kívül;

- kötődés az európai hálózatokhoz EU-s projekteken keresztül;

- forráshoz jutás a strukturális alapokból: EU-s projektek kidolgozása, menedzselése, monitoringja, és visszacsatolás az elkészült fejlesztésekről;

- hozzájutás a régiókat támogató egyéb támogatási forrásokhoz;

- határ menti együttműködések motorja;

- részvétel a jövő Európájának kialakításában: helyi, regionális vélemények megjelenítése a döntéshozók előtt;

- marginális csoportok elérése;

- az állampolgárok európai identitásának erősítése;

- az EU elfogadottságának növelése és az európai közvélemény formálása;

- új innovációs erőforrások megjelenítése.

E funkciók ellátása nem minden szervezetnek feladata (nem is lehet), így a döntéshozók egyik kötelessége, hogy megtalálják azokat a szervezeteket, amelyek képesek rá, s amelyeknek feladatuk is, hogy felvegyék a kapcsolatot a döntéshozókkal. Regionális szinten a szervezetek fontos feladata, hogy meg- 
tanuljanak pályázni az EU-s forrásokra (természetesen ehhez az kell, hogy legyenek pályázatok civil/nonprofit szervezetek részére is). A régiók fejlesztési folyamataiban való részvételnek több előfeltétele van, ami ahhoz kell, hogy a civil/nonprofit szervezetek aktívan közre tudjanak müködni a döntés-előkészítésben. Ezek bemutatására kerül sor a következő alfejezetben.

\section{A részvétel elófeltételei}

Mi kell ahhoz, hogy egy civil/nonprofit szervezet képes legyen a kohéziós politika formálásában érdemben részt venni? A szerző véleménye szerint a legfontosabb, hogy a szervezet képes legyen helyi, regionális szinten aktívan működni, és legyen nyitott az európai dimenziók és más civil/nonprofit szervezetek felé. A nyitottság és a kapcsolatépítés azért nagyon fontos, mert sokkal hatékonyabban tud megjelenni a civil érdek, ha nem önmagában, hanem szervezett módon kerül a döntéshozók elé. Erre viszont csak azok a szervezetek képesek, amelyek nem a mindennapi élet nehézségeivel küzdenek, hanem amelyeknek van lehetőségük projektek megvalósítására és képességük érdekeik érvényesítésére.

\section{Nemzeti, regionális szinten}

A következőkben az általam fontosnak tartott előfeltételek bemutatása következik.

- A döntéshozók pozitív attitűdje: Kiemelten fontos, hogy a civil/nonprofit szervezetek részvétele csak akkor lehet sikeres, ha két oldalról, vagyis fentről és lentről egyszerre indul meg az ez irányú akarat (Putnam 2000). Ez azt jelenti, hogy a központi állami szereplők felismerik, hogy fejleszteni a helyi szintű szereplők bevonása nélkül nem lehet, másrészt felismerik, hogy a szervezetek bevonása nem ott kezdődik, hogy elkészült dokumentumokról kérik ki a véleményüket, majd megpróbálják azokat több-kevesebb sikerrel beépíteni, hanem már a tervezés legelső lépésétől kezdve aktívan számolnak a helyi szereplők jelenlétével. Továbbá ennek figyelembevételével az EU-s pályázatok kiírása során a ci$\mathrm{vil} /$ nonprofit szervezeteket is potenciális pályázóknak kell tekinteni.

- A civil/nonprofit szervezetek pozitív attitüdje: A döntéshozók mellett a szervezeteknek is fel kell ismerniük, hogy életük és környezetük hatékonyabb alakulásához nemcsak egyéni szinten kell gondolkodniuk, hanem közösségi szinten is, és ki kell használniuk minden lehetőséget, hogy az őket érintő közügyekben, fejlesztési feladatokban véleménynyilvánítóként és megvalósítóként is részt vegyenek. E kétirányú felismerés nem történhet külön, hiszen, ha nincs állami akarat, akkor hiába vannak alulról jövő kezdeményezések, azok vagy egyáltalán nem, vagy csak nagy nehézségek árán jutnak célba, illetve, ha van állami akarat, de helyi/regionális szintű nincs, akkor nehéz motiválttá tenni az embere- 
ket. Így az egymás felé közeledő feleknek nagyjából egy időben kell elindulniuk egymás felé, és az egymás felé tartó úton találkozni, majd egymást erősítve haladni tovább.

- Az állampolgárok motiváltsága: az aktív civil/nonprofit szervezeti jelenléthez szükség van arra, hogy az állampolgárok (akik alapítói a szervezeteknek) is aktívak és érdekeltek legyenek, tudatosuljon bennük, hogy van beleszólásuk a körülöttük történő dolgokba. Ahhoz, hogy az állampolgárok aktívak és motiváltak legyenek arra, hogy egyénileg vagy civil/nonprofit szervezeteken keresztül részt vegyenek az életüket érintő döntésekben, szükség van arra, hogy az emberek között legyenek olyan kapcsolati hálók, amelyek lehetővé teszik, hogy képesek legyenek együtt cselekedni.

- Erős civil szektor megléte (Dezseri 2008), amely az alábbiakkal jellemezhető: -Belső tényezők: megfelelő bevételi szerkezet, hatékony irányítási és menedzserfunkciók, megfelelő érdekérvényesítő képesség, megfelelő foglalkoztatási szerkezet, széles körű kapcsolatrendszer, együttműködési hálózatok, világos jövőkép, rugalmasság (belső, külső környezetre történő reagálás), hatékony programok.

-Külső tényezők: megfelelő jogszabályi háttér, megfelelő politikai környezet, társadalmi elfogadottság, gazdasági elfogadottság, a társadalmi tőke magas szintje.

Az önkormányzatok civilbarát politikájának ismérvei a következők (Nizák 2001):

- segítik a szervezetek alapítását,

- támogatják a müködésüket,

- megteremtik a szervezetek működési alapfeltételeit,

- elismerik a szervezetek autonómiáját,

- lehetőséget teremtenek a helyi döntés-előkészítésben való részvételre, - segítik a szervezetek szolgáltatótevékenységét.

- A bizalom: A részvételi demokrácia működésének alapját képezi az állami, piaci és társadalmi szereplők bizalma egymás és az országban zajló folyamatok iránt. Ha bízunk valakiben vagy valamiben, akkor cselekedeteink során nem kell állandóan azzal foglalkozni, hogy mi történik, ha a másik fél nem úgy cselekszik, ahogy megígérte. Így lehetővé válik, hogy a bizalommal teli gazdasági és társadalmi folyamatok során teljes mértékben az adott folyamatokra koncentráljunk, hatékonyabb lesz a megvalósítás folyamata és a végeredmény is. Azokban az országokban, ahol az emberek megbíznak az őket irányító testületekben, hivatalokban, jobban fog működni a gazdaság (például a nagyobb adófizetési hajlandóság miatt), a társas viszonyok kiegyensúlyozottabbak lesznek a kölcsönös bizalom miatt (Putnam 2000). A bizalom hiánya mind a kormány, mind a társadalom számára megnövekedett költségekkel jár.

Ha egy országban erős a civil/nonprofit szektor, ha sok, a fenti tulajdonságokkal rendelkező szervezet működik, nagyobb lesz az a szervezeti kör, amely képes aktívan részt venni a kohéziós politika alakításában. 


\section{EU-s szinten}

EU-s szinten véleményem szerint az alábbi feltételek sorolhatók fel:

- Az EU-s döntéshozók pozitív attitűdje: Hasonlóan a helyi, regionális szereplőkhöz, az unió döntéshozói estében is fontos annak felismerése, hogy a civil/nonprofit szervezetekkel való együttmüködés hatékonyabb döntéseket eredményez.

- A kohéziós politikában aktív EU-intézmények pozitív attitüdje: Nemcsak a döntéshozó személyeknek, hanem az őket alkalmazó szervezeteknek is fel kell ismerni, hogy az együttműködésnek több az előnye, mint a hátránya. Legfóbb előny lehet, hogy az intézmények is hatékonyabban müködhetnek, nemcsak a fejlesztési folyamat.

- Bizalom: az erről alkotott véleményem EU-s szinten megegyező az előző alfejezetben leírtakkal.

\section{A részvétel ideális szintje: a partnerség}

Már utaltam rá, hogy a részvétel ideális formája a partnerség, ami különösen fontos a kohéziós politika esetében, hiszen ez működésének egyik alapelve. Ebben az alfejezetben röviden ismertetem, hogy mit értek partnerségen.

A partnerség (Pálné 2008) együttmüködést jelent a különféle szintek gazdasági és társadalmi szereplői között a különböző programok célkitűzésétől kezdve a megvalósításig. Az együttműködéseknek két metszete van. A vertikális metszet a fejlesztőmunka azon aspektusát érinti, amelynek keretében a döntéshozó szervek, területi egységek a célok megvalósítása érdekében bevonják az érintett társadalmi, gazdasági szereplőket a folyamatokba. A partnerség sohasem csak felülről irányított, ebben az együttműködésben a bevont szereplők kezdeményező félként is beleszólhatnak a tervezésbe, megvalósításba. A horizontális vetület a folyamatokba bevont (helyi) szereplők együttműködését jelenti közös jövőkép és programok kialakítása céljából. Ahhoz, hogy a partnerség müködjön, két dologra van alapvetően szükség, a feladatok, hasznok és a felelősség megosztására, illetve a partnerség résztvevői közötti egyre magasabb szintre jutó kapcsolatra.

A kohéziós politikában a partnerség egy másfajta megközelítése is érvényben van (Arató, Bartal, Kónya, Nizák 2008), ez alapján a partnerség elve három szinten jelenik meg:

1. az EU és a tagállamok adott szerveinek együttműködése,

2. a tagállamokon belül a nemzeti és a regionális szint közötti együttmúködés,

3. a kormányzati szereplők és a civil/nonprofit szervezetek együttműködése (jelen tanulmány erre koncentrál).

Fontos kiemelni, hogy a civil/nonprofit szervezetek köre a partnerségi együttműködésben részt vevők közé csak 1993-ban került be az EU kohéziós politikájában, ezáltal a kohéziós politika szemléletváltásáról beszélhetünk. 
Ahhoz, hogy a partnerség hatékonyan működjön, vagyis az érintett szereplők elmondhassák gondolataikat, javaslatokat tehessenek (annak érdekében, hogy a célok és fejlesztési elképzelések terén egyetértés alakulhasson ki a felek között), viszonylag hosszú időnek kell eltelni; néhány nap alatt nem lehet megfelelő együttműködéseket kialakítani.

A hatékony fejlesztésekbe történő bevonás egyik nagyon fontos szempontja, hogy a szereplőket nem politikai, gazdasági előjogok, érdekek motiválják, hanem az a közös belátás, hogy lakóhelyük, környezetük szebbé, élhetőbbé tételének érdekében kell részt venni a folyamatokban. Amennyiben kizárólag vagy nagyrészt politikai, személyes érdekek dominálnak, a fejlesztések nem a helyi igényeket, hanem egy kisebb szereplői kör szükségleteinek kielégítését szolgálják. A partnerség alapelvei között található a folyamatosság, a visszacsatolás, az esélyegyenlőség és a koordináció elve is (Fodor et al. 2003). Az elvek mindegyike az együttműködés fontosságát helyezi előtérbe, illetve utal arra, hogy nemcsak a tervezés, hanem az egész megvalósítási folyamat során szükség van arra, hogy a partnerek végigkövessék a fejlesztés minden szakaszát.

A partnerségi kapcsolatok jelentőségét az adja (Gerston 2002), hogy gyakorlatilag minden társadalmi és gazdasági szereplő kapcsolatban van egymással a világban közvetlenül vagy közvetve, minden szereplő az általa képviselt kapcsolatok révén egy-egy rendszer részét jelenti. A rendszerek jövője attól függ, hogy egymással a szereplők milyen formában és milyen mélységben képesek közös ügyek érdekében együttműködni.

\section{Kelet-közép-európai hiányosságok}

Az, hogy a civil/nonprofit szervezetek részvétele mennyire valósul meg hatékonyan, sok mindentől függ - ahogy azt láttuk egy korábbi alfejezetben is. Viszont az, hogy a civil társadalom mennyire erős, az önkormányzatok mennyire civilbarátok, a bizalom milyen szintủ az országban, nagymértékben függ az adott ország történelmi múltjától, a társadalmi, gazdasági folyamatok sajátosságaitól is. Bőhm Antal (1999) alapvetően az állampolgárok aktivitásának szerepére hívja fel a figyelmet a civil/nonprofit szektor hatékony müködésével kapcsolatban. Azokban az országokban alakulhat ki erős civil/nonprofit szektor, ahol az állampolgárok képesek az államtól független szervezeteiket létrehozni, és nagyarányban tagként vagy egyéb formában tevékenykedni bennük. Ahol az állampolgárok életére az egyéni stratégiák kialakítása és a privát szférába való visszavonulás a jellemző, ott kevésbé lehet hatékony a szektor működése. Bőhm szerint ez utóbbi jellemzi főként a volt szocialista országokat, ahol jelenleg is a szektor formálódásának lehetünk tanúi. Szakál Gyula (2004) kiemeli, hogy az erős civil/nonprofit szektor egyik alapfeltétele a társadalmi tőke jelenléte, amely még szintén hiányosan jelenik meg az említett országok többségében. 
A civil társadalom erőteljesen formálódik még, a szervezetek jelentős része küzd vezetési, szervezési és finanszírozási gondokkal (Kuti 1998, Bartal 2005), amelyek mind megnehezítik a kapcsolatok kiépítését és az európai dimenzióban való gondolkodást. Az állami és piaci szerepek még nem teljesen tisztázódtak, a szervezetek érdekképviselete hiányos. Ezzel a hátérrel nem egyszerü érdemi feladatokat ellátni, valódi társadalmi problémákra megoldási javaslatokat adni és konkrét lépéseket tenni. Természetesen vannak olyan szervezetek - szerencsére egyre többen -, amelyek aktívan végzik tevékenységüket, jelentős kapcsolati hálóval rendelkeznek, és érdemben hozzá tudnak szólni az európai dimenzióban történtekhez is. A cél az, hogy minél több ilyen szervezet legyen a volt szocialista országokban is.

Dezseri Kálmán (2008) egy tanulmányában összefoglalta, hogy melyek a térség civil/nonprofit szervezeteinek a fó hiányosságai a kohéziós politika programozási és megvalósítási folyamatában. A következőkben ezeket mutatom be.

A programozás során az alábbi hiányosságok jellemzők (Dezseri 2008):

- az előkészítő munkába nem mindig vonják be a szervezeteket,

- kevés információ áll rendelkezésre,

- nincs visszajelzés a partnereknek,

- sokszor menet közben történnek módosítások,

- a konzultációs folyamat későn kezdődik,

- kevés az erős civil/nonprofit szervezet,

- a részvétel alapvetően kész dokumentumok véleményezésére irányul. A megvalósítás során fellépő hiányosságok a következők (Dezseri 2008):

- a civil/nonprofit szervezetek jellemzően nincsenek jelen a megvalósításért felelős intézményekben,

- adott szempontok alapján kiválasztott szervezetek vannak közel a tüzhöz, így a többiek nem tudnak érvényesülni, mert nem engedik őket,

- hiányos az információáramlás,

- a projektekről való döntés gyakran politikai befolyás alatt áll,

- a szervezetek vezetői, munkatársai gyakran önkéntesek, akiknek nincs elég idejük az adott üggyel foglalkozni, így kevésbé szakértő módon tudnak a témához hozzászólni.

Egy Közép- és Kelet-Európában folytatott kutatás ${ }^{7}$ a civil/nonprofit szervezetek részvételének legnagyobb problémájaként az adminisztrációs problémákat említi (Oriniakova, Dönsz é. n.). A szervezetek képviselői nem készültek fel arra, hogy EU-s pályázatokat írjanak, hogy EU-s dokumentumokat véleményezzenek vagy állítsanak össze, illetve arra sem, hogy szakértő módon kommunikáljanak, és dokumentálják a folyamatokat. A kutatás során azt is feltártam, hogy sok esetben a civil/nonprofit szervezetek nem látják munkájuk hasznát a részvételi folyamatban, nem értik, hogy miért fontos, amit csinálnak. 


\section{Hogyan lehet a részvételt a jövő́ben még sikeresebbé tenni?}

Az Európai Bizottság egy 2010-ben kiadott közleménye az egyik legfontosabb feladatnak a partnerség erősítését tartja a régiók közötti kohéziós folyamat felgyorsításában (A Bizottság közleménye az... 2010). A dokumentum hangsúlyozza a helyi fejlesztési megoldások erősítését, továbbá a társadalmi szereplők, köztük kiemelten a civil társadalom képviseletét helyi és regionális szinten.

A Bizottsághoz hasonlóan az Európai Gazdasági és Szociális Bizottság is a partnerség erősítését és a civil társadalom minél szélesebb körü bevonását szorgalmazza a kohéziós politika jövőjére vonatkozóan (Opinion of the... 2010). Továbbá szorgalmazza jó gyakorlatokból álló kézikönyv kiadását, amelyből a szervezetek ötleteket meríthetnek a kohéziós politikában való részvétel gyakorlatára vonatkozóan. Ezenkívül célszerünek tartják egy olyan lista összeállítását, amely a potenciális partnerek elérhetőségét tartalmazná a könnyebb kapcsolatfelvétel érdekében.

A civil/nonprofit szektorral való együttműködés fontosságát és fejlesztését hangsúlyozza a Barca Report (Barca 2009) és az 5. Kohéziós jelentés is (European Union 2010), mely utóbbi továbbá kiemeli, hogy a helyi fejlesztéspolitikának egyre hangsúlyosabb szerepet kell adni, így mind jelentősebbé válik, hogy a helyi szerveződések mennyire képesek aktívan véleményt nyilvánítani. A jövő egyik nagy feladata, hogy a helyi és regionális szintű szervezetek egyre hangsúlyosabb szerepet kapjanak, továbbá megtalálják azokat a kommunikációs formákat, amelyek megfelelnek ennek a feladatnak. A helyi fejlesztés koncepciójának lényege az, hogy olyan széles körü megnyilatkozásként értelmezhető, amelyben adott számú társadalmi és gazdasági szereplő egymást kiegészítve adott helyi szinten olyan feladatokat hajt végre, amelyek eredményeképpen a helyi erőforrások lehető legjobb kihasználtsága valósul meg, és a terület fejlődik (OECD 1999). Vagyis az EU célja éppen az, hogy egy adott régió felzárkózásának folyamata helyben dőljön el.

Andor László 2010-ben a kohéziós politika jövőjével kapcsolatban azt mondta, hogy minden társadalmi és gazdasági szereplő fontos a kohéziós politika előkészítési és megvalósítási folyamatában (Andor 2010, 3.): „Minden szereplő számít, és minden szereplő segíteni tudja az Európai Bizottság munkáját annak érdekében, hogy hatékony törvényhozási munka valósuljon meg...".

A kohéziós politika hatékonyságát jelentősen növelné, ha az országok és a régiók is készítenének saját részvételi tervet arra vonatkozóan, hogy milyen szereplőket milyen helyi és régiós döntéshozatali folyamatba vonnának be, milyen időtartamra és milyen technikákat alkalmaznának (ECAS 2009).

A világban folyamatosan terjednek a különböző részvételi technikák, a kohéziós politika hatékonyabbá tétele érdekében szükség lenne ezek folyamatos bevezetésére és egyre nagyobb arányban történő alkalmazására. Véleményem szerint a számos technika és módszer közül az alábbiak alkalmazására lenne 
szükség (ezen technikák nemcsak a civil/nonprofit szervezetek, hanem az állampolgárok számára is nyitottak):

- Részvételi költségvetés (participatory budgeting): „...a települési költségvetés összetételének és arányainak a meghatározása és működésének az ellenőrzése egy minden lakos számára nyitott és átlátható, évente újraismétlődő vita- és tervezési folyamaton keresztül” (Pataki 2007, 145.). Ennek gyakorlata egy brazil városból, Porto Alegréből indult, azonban ma már több településen is alkalmazzák ezt a technikát.

- Állampolgári tanács (citizen's jury): Ennek lényege, hogy létrehoznak egy úgynevezett „mini-társadalmat”, mely 12-25 fós laikus civil emberből áll, akik adott napon át egymással vitázva alakítják ki a települést érintő problémák megoldásának közös álláspontját. Gyakorlatilag a vita végére közpolitikai javaslatokat fogalmaznak meg a települési döntéshozók számára. Egy-egy ilyen ülés akár több napig is eltarthat, ezenkívül az esemény előtt a tanács tagjai felkészítő rendezvényeken ismerhetik meg az ügy részleteit (Elliot et al. 2005). A módszer egyaránt alkalmas arra, hogy helyi és nemzeti szintü ügyeket tárgyaljanak meg, helyi szinten gyakori, hogy a jelen lévő közönség soraiban ott ülnek a település döntéshozói is.

- Konszenzus-konferencia (consensus conference): olyan nyilvános találkozó szakértők és állampolgárok között, amelynek során valamilyen technológiai, fejlesztési kérdéseket vitatnak meg, annak érdekében, hogy javaslatokat lehessen tenni helyi és nemzeti szintü szabályozásra (Elliot et al. 2005).

- Városi konferenciák (city conferences): A városi konferenciák egyszerre személyes, aktív kommunikációt lehetővé tevő, másrészt nagyméretű tömegrendezvények, amelyek ötvözik a hagyományos kommunikációs módokat a modern világ technológiai lehetőségeivel (Elliot et al. 2005, www.peopleandparticipation.net). A rendezvények lényege, hogy egyszerre több száz, akár több ezer ember véleményét képes feldolgozni.

- Vitázó közvélemény-kutatás (deliberative poll): A módszer azon az elgondoláson alapul, hogy szükség van olyan kutatási módszertanra, amely nemcsak megkérdezi az emberek véleményét, hanem lehetőséget ad arra is, hogy a kialakított véleményeket ütköztessék, sőt a módszer keretein belül arra is lehetőség van, hogy az emberek véleményét egyegy téma részletes megismerése előtt és után is megismerjék. A nemzetközi tapasztalat azt mutatja, hogy az emberek véleménye információk birtokában sokszor teljesen más, vagy legalábbis árnyaltabb, mint az információk megszerzése előtt volt (Lukensmeyer, Bringham 2005).

- Jövőműhely (future search): a közösség aktivizálása céljából létrejövő kezdeményezés, amelynek lényege, hogy az állampolgárok közösen tervezik meg a környezetük jövőjét különböző rendezvények, találkozók megszervezésén keresztül (www.peopleandparticipation.net). 


\section{Összegzés}

Tanulmányom célja az volt, hogy bemutassam, milyen szerepe lehet a civil/nonprofit szervezeteknek a kohéziós politika folyamatában. Elméleti megalapozásként ismertettem a civil/nonprofit szervezetek fogalmi rendszerét, a részvételi demokrácia koncepcióját, majd a kohéziós politika alakításában való részvétel módjait, előnyeit és jövőbeli lehetőségeit. Megállapítottam, hogy a kohéziós politika jövője egyértelműen a társadalmi szereplők bevonásának erősítését kell, hogy jelentse, vagyis a civil/nonprofit szervezetek véleményére szükség van a tervezés, a megvalósítás és az értékelés során is. Ezek technikáit tanulni kell, ami a kelet-közép-európai országokban még gyerekcipőben jár, a tanulmányban felsoroltam ezek hiányosságait, majd megfogalmaztam a javaslatokat is.

Ahhoz, hogy a tanulmányban felsorolt folyamatok müködőképesek lehessenek, a civil/nonprofit szervezeteket és a döntéshozókat képessé kell tenni arra, hogy felismerjék, hogy együtt van szükség rájuk a hatékony fejlesztési folyamatok érdekében. A hatékony kohéziós politika egyik alapja, hogy a helyi, regionális, nemzeti és EU-szintü szereplők egymással intenzív kommunikációt tartsanak fenn, képesek legyenek egymással partnerségben együttműködni. A képessé tevés azon szakemberek feladata lehet többek között, akik megfelelő eleméleti és gyakorlati tudás birtokában rendezvények, fórumok, oktatás keretei között át tudják adni az érintett szereplőknek az aktív részvételt megalapozó ismereteket.

A tanulmányban röviden ismertettem a kelet-közép-európai hiányosságokat is. Úgy gondolom, hogy az emberek közötti bizalom visszaállítása jelentheti a részvételi aktivitás növekedésének bázisát ebben a térségben. Ennek véleményem szerint két útja van: egyrészt a történelmi sajátosságok miatt szükség van arra, hogy az emberek a demokrácia tanulása során saját maguk által megtapasztalva jöjjenek rá arra idővel, hogy mit jelent megbízni a társadalmi, gazdasági szereplőkben. Másrészt szükséges lehet például civil/nonprofit szervezetek kezdeményezésével olyan találkozók szervezése, ahol a felek kötetlen beszélgetések során megismerhetik egymás gondolatait, továbbá tanulhatják saját tapasztalatok alapján az egymás közötti kommunikációt.

Véleményem szerint a kohéziós politika jövőjében a civil/nonprofit szervezetek nagyobb teret fognak kapni, nemcsak azért, mert ezt a különböző európai uniós dokumentumok is szorgalmazzák, hanem azért is, mert a társadalmi, gazdasági folyamatok egyre összetettebbé válása miatt a jó és hatékony döntések meghozatalához egyre kevésbé lesz elég a döntéshozók zárt világa, egyre nagyobb mértékben szükséges lesz a társadalom szereplőinek aktivitása is. Ehhez meg kell ismerni és alkalmazni kell azokat a részvételi módszereket, technikákat, amelyekkel teret lehet adni az állampolgároknak, civil/nonprofit szervezeteknek véleményük közvetítésére. Továbbá úgy gondolom, hogy ahhoz, hogy legyenek erős és európai szinten gondolkodni képes szervezetek, 
szükség van olyan helyi és területi szervezetekre, amelyek nemcsak saját tagja$i k$, hanem szűkebb, tágabb környezetük érdekeit is szem előtt tudják tartatni, és képviselni is tudják érdekeiket, ezáltal nemzeti és nemzetek feletti szinten egyre inkább képesek lesznek aktivitást mutatni.

Egy ország demokratikus működéséhez mind társadalmi, mind gazdasági értelemben szükség van arra, hogy a fejlesztési folyamatokban minden szereplő részt vegyen az állami, önkormányzati szereplők mellett, akik érintettek a fejlesztésekben. Így egyrészt hatékonyabb döntések születhetnek, másrészt az emberek közösségi integrációja is elősegíthető.

\section{Jegyzetek}

1 A társadalmi tőke definiálására már számtalan megközelítés született, a tanulmány az alábbiakat helyezi előtérbe: Bourdieu (1998) a társadalmi tőkét olyan erőforrások összességeként definiálja, melyek kölcsönös ismertségen alapulnak és tartós kapcsolati hálót eredményeznek. Coleman (1996) ezt a fajta tőkét pedig az egyes személyek közötti strukturált viszonyokban értelmezi. Putnam (2000) továbbá kifejti, hogy a társadalmi tőke jelenléte a közösségi kapcsolatokat egészségesebbé és gazdagabbá teheti, megtanítja az embereket arra, hogy egyszerúbb együtt gondolkodni, ezáltal nő a társadalom problémamegoldó képessége is.

2 Magyarországon a civil/nonprofit szervezetek közel fele éves szinten kevesebb mint félmillió forintból gazdálkodik, ami gyakorlatilag a „túléléshez” elég, komoly feladatok ellátására, szakemberek alkalmazására nincs lehetősége.

3 A tanulmány a civil szervezetek és a nonprofit szektor egymáshoz való viszonyát magyarországi megközelítésből mutatja be.

4 AZ EU-s dokumentumok a civil szervezet kifejezést használják.

5 Bár a részvételi demokrácia és a részvétel gondolata a 20. század második felében helyeződött előtérbe, gyökerei már a történelmi múltban megtalálhatók. Arisztotelész (1984) Politika című művében kifejtette, hogy egy állampolgár csak akkor lehet teljes értékű, ha aktívan közreműködik és részt vesz a városállam közügyeiben, másrészt a városállam egysége is csak akkor alakulhat ki, ha a polgárok részt vesznek a közösségi életben.

6 Az állampolgárok és a civil/nonprofit szervezetek részvételét társadalmi részvételnek hívjuk.

7 A kutatást (Oriniakova, Dönsz é. n.) az SFteam (SFteam for Sustainable Future: „Strukturális Alapok" Hálózat a Fenntartható Jövőért) tagszervezetei végezték Bulgáriában, Csehországban, Lengyelországban, Lettországban, Lengyelországban, Magyarországon és Romániában. A kutatást civil/nonprofit szervezetek és EU-s forrásokért felelős intézmények körében folytatták kérdőív és mélyinterjúk formájában az alábbi témákban: partnerség a programozásban, tervezésben; partnerség a monitoringban; civil/nonprofit szervezetek mint EU-s támogatásban részesülő szereplők.

\section{Irodalom}

Andor, L. (2010): The European Social Fund and the Future of Cohesion Policy. Speaking points - Press conference of Commissioners Johannes Hahn and László Andor on the 5th Cohesion Report. Brussels, 10 November 2010.

Anheier, H. K., Salamon, L. M. (1995): Szektor születik. Nonprofit Kutatócsoport, Budapest 
Arató K. (2000): Szociális párbeszéd az Európai Unióban. Doktori disszertáció. Budapesti Közgazdaságtudományi és Államigazgatási Egyetem, Nemzetközi Kapcsolatok PhD-Program, Budapest

Arató K. (2005): A civil szervezetek és az Európai Unió. Civil Szemle, 4., 102-131.

Arató K., Bartal A. M., Kónya M., Nizák P. (2008): Az Európai Unió Strukturális Alapjai és a partnerség elve Magyarországon. Rejtjel Kiadó, Budapest

Arisztotelész (1984): Politika. Gondolat, Budapest

Arnstein, S. R. (1969): A Ladder of Public Participation. Journal of the American Institute of Planners, 4., 216-224.

Barca, F. (2009): An Agenda for a reformed cohesion policy. A place-based approach to meeting European Union challenges and expectations. Independent Report. http://ec.europa.eu/regional_policy Letöltve: 2010. január 10.

Bartal A. M. (1999): Nonprofit alapismeretek kézikönyve. Ligatúra Kiadó, Budapest

Bartal A. M. (2005): Nonprofit elméletek, modellek, trendek. Századvég Kiadó, Budapest

Bőhm A. (1999): Civil szervezetek a helyi társadalomban. Comitatus, 3., 19-26.

Bourdieu, P. (1998): Gazdasági tőke, kulturális tőke, társadalmi tőke. In: Lengyel Gy., Szántó Z. (szerk.): Tókefajták: A társadalmi és kulturális erőforrások szociológiája. Aula, Budapest, 155-176.

Burns, D., Hambleton, R., Hogget, P. (1994): The Politics of Decentralisation: Revitalising Local Democracy. Macmillan

Chanan, G. (1997): Active Citizenship and Community Involvement: Getting to he Roots. Discussion Paper. European Foundation for the Improvement of Living and Working Conditions

Coleman, J. S. (1996): Társadalmi tőke. In: Lengyel Gy., Szántó Z. (szerk.): A gazdasági élet szociológiája. BKE Szociológia és Szociálpolitikai Tanszék, Budapest, 99-129.

Coleman, S. (2005): Direct representation: towards a conservational democracy. Isntitute for Public Policy Research, London. www.ippr.org Letöltve: 2009. január 10.

Csanády D. (1998): A civil társadalom szerkezete. In: Tóbiás P. (szerk.): Együttmüködési lehetőségek civil szervezetek és a helyi önkormányzatok között. Demokratikus Jogokért Fejlesztési Alapítvány, Budapest, 24-32.

Dezseri, K. (2008): Civil society participation in the Structural and Cohesion Policies in Central-European new member states. EU - CONSENT. www.eu-consent.net Letöltve: 2011. január 12.

ECAS [European Citizen Action Service] (2005): Civil Society as a partner in European Union Structural Funds. www.ecas.org Letöltve: 2011. január 12.

ECAS [European Citizen Action Service] (2009): Working Paper on the application of the partnership principle in EU cohesion policy. www.europe-centre.eu Letöltve: 2011. január 15.

Elliot, J., Heesterbeek, S., Lukensmeyer, C. J., Slocum, N. (2005): Participatory Methods Toolkit - A practitioner's manual. King Baudouin Foundation, Flemish Institute for Science and Technology Assessment (viWTA), Belgium. www.viwta.be Letöltve: 2010. április 10.

European Union (2010): Investing in Europe's Future. Fifth report on economic, social and territorial cohesion. http://ec.europa.eu/regional_policy Letöltve: 2011. január 12.

Fodor Á., Kálmán Sz., Lovász Gy., Németh Á., Wächter B. (2003): Partnerség figyelembevétele a területfejlesztésben, különös tekintettel a civil szervezetekre. VÁTI Stratégiai Tervező Iroda, Budapest

Gerston, L. N. (2002): Public Policymaking in a Democratic Society. M. E. Sharpe, New York, London

Gesztnié Ajtósi J., Csanády D. (2003): Együttmüködés a harmadik szektorral. Európai Tükör, Műhelytanulmányok 91.

Harsányi L. (1999): A harmadik szektor. In: Tóbiás P. (szerk.): Együttmúködési lehetőségek civil szervezetek és a helyi önkormányzatok között. Demokratikus Jogokért Fejlesztési Alapítvány, Budapest, $9-23$.

Horváth Z. (2007): Kézikönyv az Európai Unióról. hvgorac Lap- és Könyvkiadó Kft, Budapest

Jenkins, R. M. (1997): A nonprofit szféra és a politikai rendszer kapcsolata Magyarországon. In: Balogh E., Bullain, N., Simon I. (szerk.): Egymás jobb megértése felé. A Civil Társadalom Fejlődéséért Alapítvány, Budapest, 7-14.

Kákai L. (2004): Önkormányzunk értetek, de nélkületek! Századvég Kiadó, Budapest

Kákai L. (2009): Kik is vagyunk mi? Civil szervezetek Magyarországon. IDResearch Kft., Publikon Kiadó, Pécs

Kende P. (1999): Megjegyzések a civil társadalomról. Comitatus, 3., 12-19. 
Kulcsár K. (1997): Politikai rendszer és politikai kultúra. In: Glatz F. (szerk.): A demokrácia intézményrendszere Magyarországon. Magyar Tudományos Akadémia, Budapest, 11-31.

Kuti É. (1998): Hívjuk talán nonprofitnak... Nonprofit Kutatócsoport, Budapest

Lukensmeyer, C. J., Bringham, S. (2005): Taking Democracy to Scale - Large Scale Interventions for Citizens. The Journal of Applied Behavioral Science, 1., 47-60.

Merkel, W. (1997): Elmélyíteni és kiszélesíteni? Az európai integráció korlátai. Politikatudományi Szemle, 2., 5-32.

Nárai M. (2008): A nonprofit szervezetek helye és szerepe a helyi társadalmak életében - A nyugat-dunántúli nonprofit szektor helyzetfeltárása. Doktori disszertáció, ELTE Társadalomtudományi Kar, Szociológiai Doktori Iskola, Győr-Budapest

Nizák, P. (2001): Role of NGOs in the Local Decision-Making Processes - Example of Hungary. Citizens' Participation in Local Self-Government. Fridrich Ebert Stiftung, Zagreb Office, Zagreb. 25-39.

Nizák P., Péterfi F. (2005): A közösségi részvétel - társadalmi és hatalmi beágyazottság. In: Márkus E. (szerk.): Ismerd, értsd, hogy cselekedhess. EMLA, Budapest

OECD [Organisation for Economic Cooperation and Development] (1999): Best Practices in Local Development

Offe, C. (1991): Az egyidejűség dilemmája. Társadalmi Szemle, 8-9., 113-123.

Oriniakova, P., Dönsz T. (é. n.) (szerk.): Strukturális alapok és partnerség. Civil kutatás Közép- és Kelet-Európában. Magyar Természetvédők Szövetsége és SFteam for Sustainable Future. www.nfu.hu Letöltve: 2011. március 10.

Outer Suburban/Interface Services and Development Committee (2006): Building new communities. Melbourne. www.parliament.vic.gov/osisdc.au Letöltve: 2009. január 10.

Pálné Kovács I. (2008): Helyi kormányzás Magyarországon. Dialóg Campus, Budapest-Pécs

Pataki Gy. (2007): Bölcs „laikusok” - Társadalmi részvétei technikák a demokrácia szolgálatában. Civil Szemle, 3., 144-156.

Putnam, R. D. (2000): Bowling Alone. Simon and Schuster Paperbacks, New York

Rechnitzer J., Smahó M. (2006): Regionális politika. Elektronikus jegyzet. Széchenyi István Egyetem, Győr. jegyzet.sze.hu Letöltve: 2008. január 10.

Reisinger A. (2010): Társadalmi részvétel a helyi fejlesztéspolitikában - különös tekintettel a civil/nonprofit szervezetek szerepére. Doktori értekezés. Széchenyi István Egyetem, Győr

Sartori, G. (1999): Demokrácia. Osiris Kiadó, Budapest

Sasvári N. (2008): Civil szervezetek és az Európai Unió - Civil érdekérvényesités. Doktori dolgozat. Budapesti Corvinus Egyetem, Nemzetközi Kapcsolatok Doktori Iskola, Budapest

Scharpf, F. (1999): Governing in Europe: effective and democratic. Oxford University Press, New York

Seligman, A. B. (1997): A civil társadalom eszméje. Kávé Kiadó, Budapest

Siedentop, L. (2000): Democracy in Europe. Penguin Books, London

Szakál Gy. (2004): A társadalmi tőke hatása az oktatásra, egészségre és civil szférára. In: Szakál Gy., A. Gergely A. (szerk.): Társadalmi tóke, karrieresélyek, viselkedésminták. MTA Politikai Tudományok Intézete Etnoregionális Kutatóközpont, Budapest, 6-20.

Ugrin E., Varga Cs. (2007): Új állam- és demokráciaelmélet. Századvég Kiadó, Budapest

Young, E., Qiunn, L. (2002): Writing Effective Public Policy Papers. A Guide for Policy Advisers in Central and Eastern Europe. Local Government and Public Service Reform Initiative, Budapest. http://lgi.osi.hu Letöltve: 2011. január 15.

Európai uniós dokumentumok

A Bizottság közleménye az Európai Parlamentnek, a Tanácsnak, az Európai Gazdasági és Szociális Bizottságnak, a Régiók Bizottságának, az Európai Beruházási Banknak - A gazdasági, szociális és területi kohézióról szóló ötödik jelentéssel kapcsolatos következtetések: a kohéziós politika jövője. COM (2010) 642/3. Brüsszel, 2010

Az Európai Bizottság és a nem kormányzati szervezetek: szorosabb partneri kapcsolat. Európai Bizottság, Brüsszel, 2000

European Governance. A White Paper. COM (2001) 428. Brüsszel, 2001

Opinion of the European Economic and Social Committee on How to foster efficient partnership in the management of cohesion policy programmes, based on good practices from the 2007-2013 cycle. ECO/258. Brüsszel, 2010 
Az önkéntes szervezetek és az alapítványok európai szerepvállalásának erősítéséről. COM (97) 241, Európai Bizottság, Brüsszel, 1997

A szervezett civil társadalom szerepe és hozzájárulása az európai konstrukciókhoz. Közlemény. EGSZB, 1999

Lisszaboni Szerződés - Az Európai Unióról szóló szerződés és az Európai Közösséget létrehozó Szerződés módosításáról. (2007/C 306/01), 2007

Internetes forrás

www.peopleandparticipation.net 


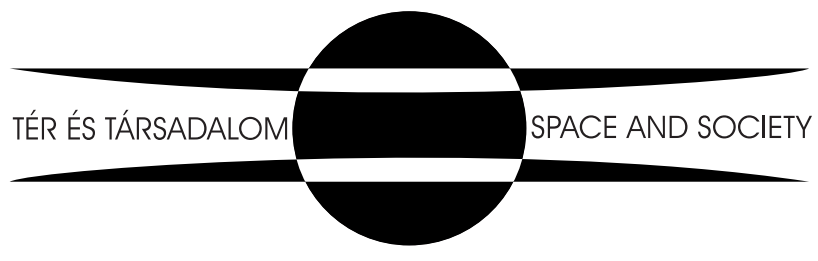

